\title{
Flavobacterium saliperosum sp. nov., isolated from freshwater lake sediment
}

\author{
Zhong-Wen Wang, Ying-Hao Liu, Xin Dai, Bao-Jun Wang, \\ Cheng-Ying Jiang and Shuang-Jiang Liu
}

Correspondence

Shuang-Jiang Liu

shuangjiang@hotmail.com

\author{
State Key Laboratory of Microbial Resources, Institute of Microbiology, Chinese Academy of \\ Sciences, Zhong-Guan-Cun, Haidian, Beijing 100080, China
}

An aerobic, yellow-pigmented, Gram-negative bacterium, designated strain $\mathrm{S}_{1}{ }^{\top}$, was isolated from freshwater sediment of Taihu Lake in central China. The taxonomy of strain $S 13^{\top}$ was studied by using phenotypic and phylogenetic methods. Cells of strain $S 13^{\top}$ were rod-shaped, non-motile and with a size range of $0.35-0.55 \times 1.5-2.5 \mu \mathrm{m}$. The nearly complete $16 \mathrm{~S}$ rRNA gene of strain $S 13^{\top}$ was amplified and sequenced. A BLAST search and phylogenetic analysis based on $16 \mathrm{~S}$ rRNA gene sequence similarity showed that strain $S 13^{\top}$ was related to members of the genus Flavobacterium, with the highest sequence similarity of $93.8 \%$ to Flavobacterium columnare (ATCC $\left.23463^{T}\right)$. Cells contained menaquinone-6 (MK-6) as the major respiratory quinone and the genomic DNA G $+C$ content was 41 mol\%. The major fatty acids were iso- $\mathrm{C}_{15: 0}(28 \cdot 2 \%)$ and iso- $\mathrm{C}_{17: 1} \omega 9 \mathrm{C}(19 \cdot 0 \%)$. It is proposed that $\mathrm{S} 13^{\top}\left(=\right.$ CGMCC $\left.1.3801^{\top}=\mathrm{JCM} 13331^{\top}\right)$ represents the type strain of a novel species, Flavobacterium saliperosum sp. nov.
The genus Flavobacterium was established by Frankland in 1889 (see Bergey et al., 1923), since when many amendments to its description have been made. Bernardet et al. (1996) defined that Flavobacterium species are Gram-negative rods, are motile by gliding, contain menaquinone- 6 (MK-6) as the sole respiratory quinone, and have DNA G $+\mathrm{C}$ contents in the range 32-37 mol\% (among other properties). The 26 species within the genus Flavobacterium that are recognized at the time of writing appear in Fig. 1 (see later). Flavobacterium species are physiologically diverse: they can be psychrophilic, psychrotolerant or mesophilic, and can be halophilic, halotolerant or sensitive to salts. As a reflection of their physiological diversity, Flavobacterium species have been isolated from various habitats such as freshwater sediments and soil (Bernardet et al., 1996; Tamaki et al., 2003; McCammon \& Bowman, 2000), a glacier (Zhu et al., 2003) and Antarctic lakes (Van Trappen et al., 2003, 2004; McCammon et al., 1998; McCammon \& Bowman, 2000; Humphry et al., 2001; Yi et al., 2005).

Taihu Lake (also known as Lake Tai; $120^{\circ} 02^{\prime} 16 \cdot 8^{\prime \prime} \mathrm{E}, 31^{\circ} 27^{\prime}$ $10 \cdot 7^{\prime \prime} \mathrm{N}$ ), in Jiangsu Province, China, is the third largest freshwater lake in China and plays an important role in the region's agriculture, aquaculture and industry. Owing to

Published online ahead of print on 13 October 2005 as DOI 10.1099/ ijs.0.64065-0.

Abbreviation: CFB, Cytophaga-Flavobacterium-Bacteroides.

The GenBank/EMBL/DDBJ accession number for the 16S rRNA gene sequence of Flavobacterium saliperosum $\mathrm{S}_{1} \mathrm{~T}^{\mathrm{T}}$ is DQ021903. accelerating economic development and lack of environmental protection, the water quality of the lake is declining, with algal blooms occurring regularly in recent years. In an attempt to understand the microbial contribution to the cycling of nutrient elements (carbon, nitrogen, sulfur), analysis of the microbial community was conducted, and a genetic clone library of $16 \mathrm{~S}$ rRNA genes derived from DNA samples of Taihu Lake sediment indicated that sequences related to the Cytophaga-Flavobacterium-Bacteroides (CFB) group accounted for $12 \%$ of the total clones (Dai et al., 2005). Thus, efforts to isolate these CFB-related bacteria were made in our laboratory. We report here the isolation and identification of one of these organisms, designated strain $\mathrm{S} 13^{\mathrm{T}}$.

To isolate Flavobacterium species, a method that combines plate culture with PCR-guided screening was established. First, colonies on agar plates were obtained by plating 10 -fold dilutions $\left(10^{-1}-10^{-5}\right)$ of lake sediment samples on dilute nutrient medium (DNM; $0.5 \mathrm{~g}$ beef extract $\mathrm{l}^{-1}, 1 \mathrm{~g}$ fish peptone $1^{-1}, 0.5 \mathrm{~g} \mathrm{NaCl} \mathrm{l}^{-1}, 15 \mathrm{~g}$ agar $\mathrm{l}^{-1}$ ) and incubating at $25^{\circ} \mathrm{C}$ for 10 days. Second, yellow-pigmented colonies were checked by PCR using a forward primer (designed here according to alignment of 16S rRNA gene sequences of some CFB group members: $5^{\prime}$-ACGGGTGGCGGAACACGTACAG-3') and a reverse primer (1468R, a general primer for bacteria: 5'-CTGGCCACAGACGTGGAG-3'). Eight of 40 colonies gave positive signals during PCR detection. DNA sequences of these eight strains showed that they have almost identical $16 \mathrm{~S}$ rRNA genes (500 bp at the $5^{\prime}$-end). One representative strain, $\mathrm{S} 13^{\mathrm{T}}$, was selected for 


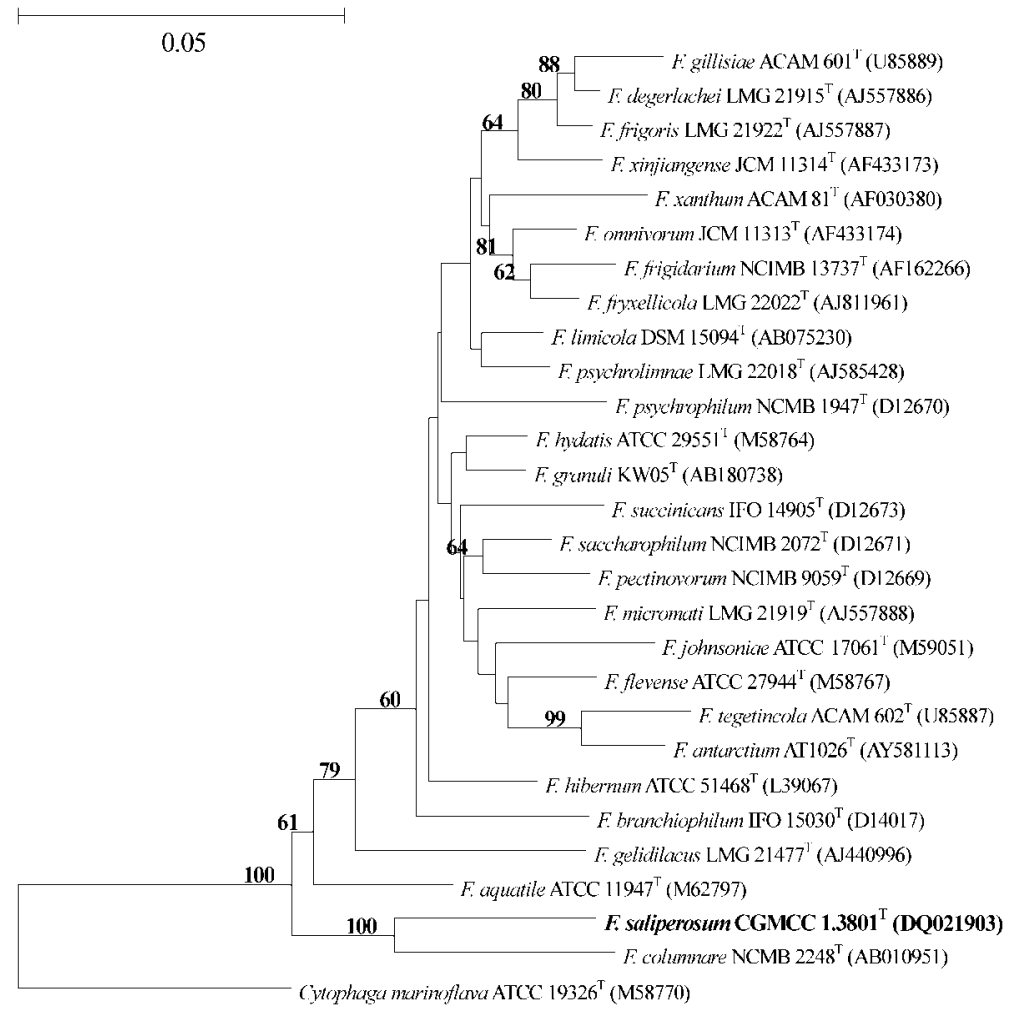

Fig. 1. Phylogenetic tree constructed with the neighbour-joining method according to 16S rRNA gene sequences of strain $\mathrm{S}_{13}{ }^{\top}$ and species of the genus Flavobacterium. Numbers at nodes indicate percentages of bootstrap support based on 1000 resampled datasets. Cytophaga marinoflava (ATCC $19326^{\top}$ ) was used as outgroup. GenBank accession numbers are given in parentheses. Bar, evolutionary distance $\left(K_{\text {nuc }}\right)$ of $0 \cdot 05$. phylogenetic analysis and for biochemical and physiological characterization.

Routine cultivation was conducted at $25^{\circ} \mathrm{C}$ with modified M1 medium (ATCC) or Shieh medium (Song et al., 1988). Gram reactions were determined according to the method described by Gerhardt et al. (1994). Cell flagellation and morphology were examined by transmission and scanning electron microscopy. Chitin hydrolysis was tested as described by Hsu \& Lockwood (1975). Hydrolysis of CMcellulose $(0.5 \%, \mathrm{w} / \mathrm{v})$, gelatin $(0.5 \%, \mathrm{w} / \mathrm{v})$, casein $(50 \%$ skimmed milk, v/v), agar $(1 \cdot 5 \%, \mathrm{w} / \mathrm{v})$, alginate $(0 \cdot 5 \%, \mathrm{w} / \mathrm{v})$, pectin $(0.5 \%, \mathrm{w} / \mathrm{v})$, aesculin $(0.5 \%, \mathrm{w} / \mathrm{v})$, starch $(0.5 \%$, w/v), L-tyrosine $(0 \cdot 5 \%, \mathrm{w} / \mathrm{v})$, Tween $80(1 \%, \mathrm{v} / \mathrm{v})$ and egg yolk $(5 \%, \mathrm{w} / \mathrm{v})$ was tested using the standard mineral base of Stanier et al. (1966). After the mineral base was autoclaved, each compound was added. Growth was examined after incubation at $25^{\circ} \mathrm{C}$ for $1,3,7$ and 14 days. Catalase and oxidase activities, Voges-Proskauer reaction, brown diffusible pigment on L-tyrosine agar and production of $\mathrm{H}_{2} \mathrm{~S}$ were also investigated according to the methods of Dong \& Cai (2001). Aerobic and anaerobic production of acids (OF reaction) from carbohydrates was determined in OF basal medium (Hugh \& Leifson, 1953). Carbohydrate solution sterilized by filtration was added at final concentration of $1 \%(\mathrm{w} / \mathrm{v})$, and acid production was recorded after 7 and 14 days incubation.

Flexirubin-type pigments were detected by using $20 \% \mathrm{KOH}$ (Fautz \& Reichenbach, 1980) and extracellar glycans were identified with the Congo red absorption test (McCammon \& Bowman, 2000). Growth temperature was determined with a TN3F temperature-gradient incubator (Advantec). Growth on seawater agar, nutrient agar and trypticase soy agar was tested at $25^{\circ} \mathrm{C}$ after 14 days growth. The presence of gliding motility was determined as described by Zhu et al. (2003). Salt tolerance was tested in M1 medium supplemented with $0-2 \% \mathrm{NaCl}$ (spun at 100 r.p.m., $25^{\circ} \mathrm{C}$ ) incubated for 3 days. Duplicate antibiotic-sensitivity tests were performed using filter-paper discs $(\varnothing 3.25 \times 0.75 \mathrm{~mm})$ containing each of the following: ceftazidime $(30 \mu \mathrm{g})$, ceftriaxone $(30 \mu \mathrm{g})$, tobramycin $(10 \mu \mathrm{g})$, trimethoprim/ sulfamethoxazole $(1 \cdot 25 / 23 \cdot 75 \mu \mathrm{g})$; penicillin (10 IU), erythromycin $(15 \mu \mathrm{g})$, tetracycline $(30 \mu \mathrm{g})$, gentamicin $(10 \mu \mathrm{g})$, chloramphenicol $(30 \mu \mathrm{g})$, azithromycin $(15 \mu \mathrm{g})$, kanamycin $(30 \mu \mathrm{g})$, streptomycin $(10 \mu \mathrm{g})$ and rifampicin $(5 \mu \mathrm{g})$. Discs were placed on M1 medium plates spread with $\mathrm{S} 13^{\mathrm{T}}$ culture and were then incubated at $25^{\circ} \mathrm{C}$ for $18-24 \mathrm{~h}$.

Cells of strain $\mathrm{S} 13^{\mathrm{T}}$ were Gram-negative and aerobic, with a size range of $0.35-0.55 \times 1 \cdot 5-2.5 \mu \mathrm{m}$. Flagella were not observed. Colonies were yellow, smooth, circular and $2-4 \mathrm{~mm}$ in diameter. Growth was observed over a temperature range of $20-34{ }^{\circ} \mathrm{C}$ and a $\mathrm{pH}$ range of $6 \cdot 5-8 \cdot 5$. Gelatin and casein were hydrolysed but starch, CMcellulose, agar, alginate, aesculin, chitin and pectin were not. A detailed description of assimilation of sugars, sensitivity to antibiotics, etc., is provided in the species description. Growth occurred without adding $\mathrm{NaCl}$ to the medium and was severely inhibited in the presence of more 
than $1 \% \mathrm{NaCl}$; the optimal concentration of $\mathrm{NaCl}$ for growth was $0.1 \%$ in medium. Differential phenotypic characteristics of strain $\mathrm{S} 13^{\mathrm{T}}$ and related Flavobacterium species are detailed in Table 1.

Biomass for chemotaxonomic analysis was harvested from modified M1 medium cultures at $25^{\circ} \mathrm{C}$ for $24 \mathrm{~h}$. Strain $\mathrm{S} 13^{\mathrm{T}}$ was further characterized for its cellular fatty acid profile. Cellular fatty acids were extracted and analysed by the Sherlock system (Midi) following the manufacturer's instructions. The most abundant cellular fatty acids of strain $\mathrm{S}_{13}{ }^{\mathrm{T}}$ were iso- $\mathrm{C}_{15: 0}(28 \cdot 2 \%)$, iso- $\mathrm{C}_{17: 1} 9 \mathrm{c}(19 \cdot 0 \%)$, iso- $\mathrm{C}_{17: 0} 3-\mathrm{OH}(8.6 \%)$ and iso- $\mathrm{C}_{15: 1} \mathrm{G}(6.7 \%)$. The cellular fatty acid profile of strain $\mathrm{S} 13^{\mathrm{T}}$ is given in the species description. Menaquinones were extracted and purified according to the method of Collins (1985) and were analysed by HPLC (Wu et al., 1989), with the MK-6 from Salegentibacter holothuriorum (NBRC $100249^{\mathrm{T}}$ ) used as a reference. S. holothuriorum NBRC $100249^{\mathrm{T}}$ was cultivated in liquid Zobell 2216E medium $\left(150\right.$ r.p.m., $\left.25^{\circ} \mathrm{C}\right)$ for 36 h. Strain $S 13^{\mathrm{T}}$ was shown to have MK-6 as the major respiratory quinone. DNA base composition was determined by thermal denaturation (Marmur \& Doty, 1962) using DNA from Escherichia coli K-12 as a control. The DNA

Table 1. Phenotypic characteristics that differentiate Flavobacterium saliperosum sp. nov. from related Flavobacterium species

Taxa: 1, Flavobacterium saliperosum sp. nov. (data from this study); 2, Flavobacterium columnare; 3, Flavobacterium aquatile; 4, Flavobacterium branchiophilum (data for 2-4 from Bernardet et al., 1996); 5, Flavobacterium hibernum (McCammon et al., 1998); 6, Flavobacterium gelidilacus (Van Trappen et al., 2003). +, Positive; - , negative; $(+)$, weakly positive; $\mathrm{V}$, variable among strains.

\begin{tabular}{|lcccccc|}
\hline Characteristic & $\mathbf{1}$ & $\mathbf{2}$ & $\mathbf{3}$ & $\mathbf{4}$ & $\mathbf{5}$ & $\mathbf{6}$ \\
\hline Growth on: & & & & & & \\
$\quad$ Seawater agar & - & - & - & - & - & + \\
$\quad$ Nutrient agar & + & - & - & - & + & + \\
$\quad$ Trypticase soy agar & $(+)$ & - & $(+)$ & - & + & + \\
Gliding motility & - & + & + & - & + & - \\
Flexirubin pigments & + & + & - & - & + & - \\
Congo red absorption & - & + & - & - & - & - \\
Acid from carbohydrates & - & - & + & + & + & - \\
Degradation of: & & & & & & \\
$\quad$ Gelatin & + & + & $\mathrm{V}$ & + & + & + \\
$\quad$ Starch & - & - & $\mathrm{V}$ & + & + & + \\
$\quad$ Aesculin & - & - & $\mathrm{V}$ & - & + & - \\
$\quad$ Tyrosine & + & - & $\mathrm{V}$ & + & + & - \\
Brown pigment on tyrosine agar & + & $\mathrm{V}$ & - & - & - & - \\
Precipitation on egg-yolk medium & + & + & + & + & - & - \\
H 2 production & - & + & - & - & - & - \\
Nitrate reduction & - & $\mathrm{V}$ & $\mathrm{V}$ & - & + & - \\
Production of cytochrome oxidase & - & + & + & + & - & + \\
DNA G +C content (mol\%) & 41 & 32 & 33 & 33 & 36 & 30 \\
& & & & & & \\
\hline
\end{tabular}

$\mathrm{G}+\mathrm{C}$ content of strain $\mathrm{S} 13^{\mathrm{T}}$ was $41 \mathrm{~mol} \%$, which is higher than that of other Flavobacterium species (32-37 mol\%).

The nearly complete $16 \mathrm{~S}$ rRNA gene of strain $\mathrm{S} 13^{\mathrm{T}}$ (1400 bp) was amplified and sequenced as described by Zhang et al. (2003). Alignments of $16 \mathrm{~S}$ rRNA gene sequences were performed with the CLUSTAL_X program, version 1.64b (Thompson et al., 1997). A phylogenetic tree (Fig. 1) was constructed by the neighbour-joining method (Saitou \& Nei, 1987) with Kimura's two-parameter calculation model (Kimura, 1980). 16S rRNA gene sequence analysis indicated that strain $S 13^{\mathrm{T}}$ was phylogenetically related to members of the genus Flavobacterium, with similarity ranging from $89 \cdot 1$ to $93 \cdot 8 \%$. Strain $\mathrm{S} 13^{\mathrm{T}}$ had highest $16 \mathrm{~S}$ rRNA gene sequence similarity to Flavobacterium columnare $(93 \cdot 8 \%)$ and to Flavobacterium aquatile $(93 \cdot 3 \%)$. The phylogenetic tree indicated that strain $\mathrm{S}_{1}{ }^{\mathrm{T}}$ clustered with $F$. columnare, and that this cluster was further grouped with the remaining recognized species of the genus Flavobacterium with strong support $(100 \%)$. Based on this phylogenetic analysis and the phenotypic properties, we concluded that strain $S 13^{\mathrm{T}}$ represents a novel, aquatic species within the genus Flavobacterium. Because it is sensitive to $\mathrm{NaCl}(1 \% \mathrm{NaCl}$ completely halted growth), we propose the name Flavobacterium saliperosum sp. nov.

\section{Description of Flavobacterium saliperosum sp. nov.}

Flavobacterium saliperosum (sal.i.per.o'sum. L. n. sal, salis salt; L. adj. perosum detesting, hating greatly; N.L. neut. adj. saliperosum salt-hating).

Gram-negative, aerobic and heterotrophic, with cell size of $0 \cdot 35-0 \cdot 55 \times 1 \cdot 5-2 \cdot 5 \mu \mathrm{m}$. Non-flagellated and non-gliding. Colonies are yellow, smooth and circular with entire margins. Grows at temperatures of $20-34{ }^{\circ} \mathrm{C}$ (optimum growth at $28^{\circ} \mathrm{C}$ ). Grows over $\mathrm{pH}$ range $6 \cdot 5-8 \cdot 5$ (optimum growth at $\mathrm{pH} 7 \cdot 5)$. A concentration of $\mathrm{NaCl}$ above $1 \%$ severely inhibits growth (optimum growth is at $0 \cdot 1 \% \mathrm{NaCl}$ in medium). Grows on nutrient agar and trypticase soy agar but not on seawater agar. Voges-Proskauer reaction and oxidase are negative but catalase and lipase are positive. Cells contain flexirubin pigments. Does not reduce nitrate or sulfate. Forms a precipitate on egg-yolk agar and produces brown pigment on tyrosine agar. Hydrolyses L-tyrosine, gelatin and casein, but not agar, alginate, aesculin, starch, $\mathrm{CM}$-cellulose, chitin or pectin. Does not produce acid from the following sugars: lactose, arabinose, rhamnose, raffinose, ribose, galactose, melibiose, D-melezitose, sucrose, xylose, mannose, fucose, fructose, glucose, cellobiose, maltose, salicin, laetrile, mannitol or sorbitol. Filter-paper disc tests indicate resistance to ceftazidime, ceftriaxone, tobramycin and trimethoprim/sulfamethoxazole, but susceptibility to penicillin, erythromycin, tetracycline, gentamicin, chloramphenicol, azithromycin, kanamycin, streptomycin and rifampicin. Cells contain menaquinone-6 (MK-6). Cellular fatty acids are iso- $\mathrm{C}_{15: 0}(28 \cdot 2 \%)$, iso- $\mathrm{C}_{17: 1} \omega 9 c(19 \cdot 0 \%)$, iso- $\mathrm{C}_{17: 0} 3-\mathrm{OH}(8.6 \%)$, iso- $\mathrm{C}_{16: 0}(6.9 \%)$, iso- $\mathrm{C}_{15: 1} \mathrm{G}$ 
$(6 \cdot 7 \%)$, iso- $\mathrm{C}_{15: 0} 3-\mathrm{OH}(5 \cdot 0 \%), \mathrm{C}_{15: 0}(4 \cdot 6 \%)$, anteiso$\mathrm{C}_{15: 0}(3 \cdot 9 \%), \mathrm{C}_{16: 1} \omega 7 c(2 \cdot 6 \%)$, iso- $\mathrm{C}_{16: 1} \mathrm{H}(2 \cdot 3 \%)$, iso$\mathrm{C}_{16: 0} 3-\mathrm{OH}(2 \cdot 0 \%)$, iso- $\mathrm{C}_{14: 0}(1 \cdot 3 \%), \mathrm{C}_{17: 0} 2-\mathrm{OH}(1 \cdot 0 \%)$, iso- $\mathrm{C}_{15: 0} \quad 2-\mathrm{OH} \quad(0 \cdot 9 \%)$, iso- $\mathrm{C}_{13: 0} \quad(0 \cdot 5 \%), \mathrm{C}_{15: 1} \omega 6 c$ $(0 \cdot 42 \%)$ and $\mathrm{C}_{17: 1} \omega 6 c(0 \cdot 3 \%)$. DNA $\mathrm{G}+\mathrm{C}$ content is $41 \mathrm{~mol} \%$.

The type strain, $\mathrm{S}^{\mathrm{T}}{ }^{\mathrm{T}}\left(=\mathrm{CGMCC} 1.3801^{\mathrm{T}}=\mathrm{JCM} 13331^{\mathrm{T}}\right)$, was isolated from freshwater lake sediment.

\section{References}

Bergey, D. H., Harrison, F. C., Breed, R. S., Hammer, B. W. \& Huntoon, F. M. (editors) (1923). Genus II. Flavobacterium gen. nov. In Bergey's Manual of Determinative Bacteriology, 1st edn, pp. 97-117. Baltimore: Williams \& Wilkins.

Bernardet, J. F., Segers, P., Vancanneyt, M., Berthe, F., Kersters, K. \& Vandamme, P. (1996). Cutting a Gordian knot: emended classification and description of the genus Flavobacterium, emended description of the family Flavobacteriaceae, and proposal of Flavobacterium hydatis nom. nov. (basonym, Cytophaga aquatilis Strohl and Tait 1978). Int J Syst Bacteriol 46, 128-148.

Collins, M. D. (1985). Isoprenoid quinine analysis in classification and identification. In Chemical Methods in Bacterial Systematics, pp. 267-287. Edited by M. Goodfellow \& D. E. Minnikin. London: Academic Press.

Dai, X., Wang, B.-J., Zhang, P. \& Liu, S.-J. (2005). Bacterial diversity in the sediments of Taihu lake by using traditional nutrient medium and dilution medium. Acta Microbiol Sinica 45, 161-165.

Dong, X.-Z. \& Cai, M.-Y. (editors) (2001). Determination of biochemical properties. In Manual for Systematic Identification of General Bacteria, pp. 370-398. Beijing: Science Press (in Chinese).

Fautz, E. \& Reichenbach, J. R. (1980). A simple test for flexirubintype pigments. FEMS Microbiol Lett 8, 87-91.

Gerhardt, P., Murray, R. G. E., Wood, W. A. \& Krieg, N. R. (1994). Methods for General and Molecular Bacteriology. Washington, DC: American Society for Microbiology.

Hsu, S. C. \& Lockwood, J. L. (1975). Powdered chitin agar as a selective medium for enumeration of actinomycetes in water and soil. Appl Microbiol 29, 422-426.

Hugh, R. \& Leifson, E. (1953). The taxonomic significance of fermentative versus oxidative metabolism of carbohydrates by various Gram-negative bacteria. J Bacteriol 66, 24-26.

Humphry, D. R., George, A., Black, G. W. \& Cummings, S. P. (2001). Flavobacterium frigidarium sp. nov., an aerobic psychrophilic, xylanolytic and laminarinolytic bacterium from Antarctica. Int J Syst Evol Microbiol 51, 1235-1243.

Kimura, M. (1980). A simple method for estimating evolutionary rates of base substitutions through comparative studies of nucleotide sequences. J Mol Evol 16, 111-120.
Marmur, J. \& Doty, P. (1962). Determination of the base composition of deoxyribonucleic acid from thermal denaturation temperature. J Mol Biol 5, 109-118.

McCammon, S. A. \& Bowman, J. P. (2000). Taxonomy of Antarctic Flavobacterium species: description of Flavobacterium gillisiae sp. nov., Flavobacterium tegetincola sp. nov. and Flavobacterium xanthum sp. nov., nom. rev. and reclassification of [Flavobacterium] salegens as Salgentibacter salegens gen. nov., comb. nov. Int J Syst Evol Microbiol 50, 1055-1063.

McCammon, S. A., Innes, B. H., Bowman, J. P., Franzmann, P. D., Dobson, S. J., Holloway, P. E., Skerratt, J. H., Nichols, P. D. \& Rankin, L. M. (1998). Flavobacterium hibernum sp. nov., a lactoseutilizing bacterium from a freshwater Antarctic lake. Int J Syst Bacteriol 48, 1405-1412.

Saitou, N. \& Nei, M. (1987). The neighbor-joining method: a new method for constructing phylogenetic trees. Mol Biol Evol 4, 406-425.

Song, Y. L., Fryer, J. L. \& Rohovvec, J. S. (1988). Comparison of six media for the cultivation of Flexibacter columnaris. Fish Pathol 23 , 91-94.

Stanier, R. Y., Palleroni, N. J. \& Doudoroff, M. (1966). The aerobic pseudomonads: a taxonomic study. J Gen Microbiol 43, 159-271.

Tamaki, H., Satoshi, H., Yoichi, K., Kazunori, N., Nakao, N., Kazunori, N. \& Masatoshi, M. (2003). Flavobacterium limicola sp. nov., a psychrophilic, organic-polymer-degrading bacterium isolated from freshwater sediments. Int J Syst Evol Microbiol 53, 519-526.

Thompson, J. D., Gibson, T. J., Plewniak, F., Jeanmougin, F. \& Higgins, D. G. (1997). The CLUSTAL_X windows interface: flexible strategies for multiple sequence alignment aided by quality analysis tools. Nucleic Acid Res 25, 4876-4882.

Van Trappen, S., Mergaert, J. \& Swings, J. (2003). Flavobacterium gelidilacus sp. nov., isolated from microbial mats in Antarctic lakes. Int J Syst Evol Microbiol 53, 1241-1245.

Van Trappen, S., Vandecandelaere, I., Mergaert, J. \& Swings, J. (2004). Flavobacterium degerlachei sp. nov., Flavobacterium frigoris sp. nov. and Flavobacterium micromati sp. nov., novel psychrophilic bacteria isolated from microbial mats in Antarctic lakes. Int J Syst Evol Microbiol 54, 85-92.

Wu, C., Lu, X. \& Qin, M. (1989). Analysis of menaquinone compound in microbial cells by HPLC. Microbiology (English translation of Mikrobiologiya) 16, 176-178.

Yi, H., Oh, H.-M., Lee, J.-H., Kim, S.-J. \& Chun, J. (2005). Flavobacterium antarcticum sp. nov., a novel psychrotolerant bacterium isolated from the Antarctic. Int J Syst Evol Microbiol 55 , 637-641.

Zhang, D., Yang, H., Zhang, W., Huang, Z. \& Liu, S.-J. (2003). Rhodocista pekingensis sp. nov., a cyst-forming phototrophic bacterium from a municipal wastewater treatment plant. Int J Syst Evol Microbiol 53, 1111-1114.

Zhu, F., Wang, S. \& Zhou, P. J. (2003). Flavobacterium xinjiangense sp. nov. and Flavobacterium omnivorum sp. nov., novel psychrophiles from the China No. 1 glacier. Int J Syst Evol Microbiol 53, 853-857. 